\title{
ANALISA BEBAN KERJA KEGIATAN ADMINISTRASI SEKOLAH DENGAN PENDEKATAN JOB MAPPING
}

\author{
Gusti Adriansyah ${ }^{1}$, Nizar $^{2}$ \\ Teknik Industri, Fakultas Teknik \\ Universitas Maarif Hasyim Latif, Sidoarjo, Indonesia \\ e-mail : 1gusti@dosen.umaha.ac.id,2nizar@yahoo.com \\ Diterima: 18 April 2018. Disetujui : 15 Juni 2018. Dipublikasikan : 29 Juni 2018 \\ (C)2018 -TESJ Fakultas Teknik Universitas Maarif Hasyim Latif. Ini adalah artikel dengan \\ akses terbuka di bawah lisensi CC BY 4.0 (https://creativecommons.org/licenses/by/4.0/)
}

\begin{abstract}
ABSTRAK
Persaingan antar lembaga pendidikan sekolah swasta semakin ketat. Dalam kondisi seperti ini sangat penting bagi suatu lembaga pendidikan dalam hal ini SMA XYZ Sukodono untuk dapat mengoptimalkan sumber daya, guru dan pegawai yang ada guna memenuhi kebutuhan masyarakat dalam pelayanan dan sarana pendidikan. Saat ini sekolah mempunyai sebuah permasalahan tentang pembagian beban kerja yang sudah ada, sehingga terjadi kurang optimalnya guru, staf dan pegawai yang ada. Oleh karena itu dalam penelitian ini digunakan pendekatan metode job mapping sebagai alat bantu dalam membantu memetakan pekerjaan untuk memudahkan melakukan upaya perbaikan beban kerja. Proses ini yang dilakukan untuk menghindari evaluasi jobdesc yang dilakukan secara sepihak oleh pimpinan sekolah. Dari penelitian yang dilakukan di SMA XYZ Sukodono, telah dilakukan pemetaan 92 tugas (pekerjaan) dalam matriks JM berukuran $9 \times 17$ dengan hasil penurunan total waktu kerja semua fungsi pengelolaan dari 396,51 jam per-minggu menjadi 368,35 jam per-minggu.
\end{abstract}

Kata kunci: beban kerja sekolah, jobdesc, job mapping, job redesign

\section{PENDAHULUAN}

Pada saat ini banyak sekolah yang sudah berorientasi pada kualitas pendidikan, salah satunya adalah SMA XYZ Sukodono. Persaingan antar lembaga pendidikan terutama sekolah swasta tidak dapat dihindari dan semakin ketat. Kondisi ini harus menjadi pertimbangan bagi SMA XYZ Sukodono untuk dapat mengoptimalkan sumber daya, guru dan pegawai yang ada guna memenuhi kebutuhan masyarakat. Penelitian ini membahas tentang suatu cara untuk melihat bagaimana kontribusi pekerjaan yang ada serta bagaimana melakukan perbaikan atas kondisi tersebut untuk dilakukan perbaikan dan peningkatan kualitas layanan pendidikan. Dengan menggunakan metode yang ada diharapkan nantinya mampu mengoptimalkan sumber daya yang ada, sehingga mampu meningkatkan optimalisasi beban kerja tenaga guru dan staf di SMA XYZ Sukodono.

\section{METODE PENELITIAN}

Pendekatan Job Mapping digunakan untuk melakukan desain ulang pekerjaan. Desain ulang pekerjaan sangatlah penting untuk membuat pekerja lebih optimal. Beberapa metode yang telah dikenal dan digunakan secara luas dalam melakukan desain ulang pekerjaan adalah:

1. Penyederhanaan pekerjaan, yakni pekerjaan dibuat lebih mudah (job simplification).

2. Perluasan pekerjaan, yakni:

a. Job Enlargement, merupakan teknik dalam merancang pekerjaan di mana terjadi peningkatan jumlah tugas dalam pekerjaan (dan diperlukan pelatihan yang tepat) untuk menambah berbagai hal yang berbeda dari kegiatan, sehingga mengurangi pekerjaan yang monoton.

b. Job Enrichment, merupakan suatu teknik dalam desain pekerjaan pekerja guna peningkatan motivasi dan peningkatan kepuasan kerja dengan memberikan mereka lebih banyak otoritas dengan berbagai kemampuan mereka.

c. Job Rotation, merupakan teknik untuk mengurangi rutinitas pekerja dan juga menambah pengetahuan pekerja tentang organisasi. Job rotation juga berarti perpindahan dari pekerjaan yang satu ke pekerjaan lainnya.

Untuk menganalisa beban kerja dan desain ulang pekerjaan akan menjadi lebih mudah dilakukan jika kita memiliki sebuah peta ( $m a p$ ) yang dapat menggambarkan seluruh pekerjaan yang ada (Adriansyah, 2009). Peta pekerjaan (job 
mapping) ini membantu memperlhatkan pembagian tugas dan kontribusi dari setiap individu pada suatu area organisasi. Peta ini akan memperlihatkan pada kita mana pekerjaan yang mempunyai beban lebih, beban yang masih kurang, pekerjaan yang tumpang tindih, dan kondisi yang lainnya dari seluruh pekerjaan yang ada. Peta pekerjaan ini juga memperlihatkan integrasi secara keseluruhan antara satu tugas dengan tugas lainnya terhadap suatu fungsi pekerjaan. Dengan adanya peta pekerjaan ini kita dapat melakukan analisa beban kerja dan desain ulang pekerjaan, baik untuk melakukan penyederhanaan pekerjaan maupun untuk melakukan perluasan pekerjaan, tentunya dengan cara yang lebih terukur dan terintegrasi. Dan pada akhirnya dari proses ini diharapkan akan dapat memberikan kinerja dan kepuasan kerja bagi setiap pekeja.

Pada proses perbaikan beban kerja, dapat dilakukan dengan cara memberikan pekerjaan pada pemegang jabatan yang masih mempunyai toleransi waktu kerja, dengan kata lain pada pemegang jabatan dengan beban kerja lebih dapat membagi pekerjaannya pada pemegang jabatan dengan beban kerja lebih rendah. Demikian juga sebaliknya. Dengan demikian antara seluruh pekerjaan yang ada akan tercipta keseimbangan waktu atau beban kerja dan mendorong individu untuk memberikan kinerja terbaik.

Menurut Adriansyah (Adriansyah, 2009), dalam pendekatan Job mapping, langkah-langkah desain ulang pekerjaan dapat dilakukan dengan cara sebagai berikut:

1. Tentukan area dalam organisasi yang akan diteliti.

2. Identifikasi data tugas atau pekerjaan saat ini.

3. Lakukan pengumpulan data waktu kerja dan lakukan validasi pekerjaan.

4. Lakukan pemetaan pekerjaan dari data pekerjaan saat ini.

5. Lakukan perbaikan (improvement) pada kondisi yang tidak sesuai untuk mendapatkan beban kerja yang lebih ideal bagi setiap pemegang jabatan.

\section{Penentuan area}

Penentuan area organisasi yang diteliti seperti tampak pada struktur organisasi di bawah ini. Gambar 1 adalah struktur organisasi di SMA XYZ Sukodono:

Penelitian ini mengambil kegiatan administrasi di SMA XYZ Sukodono (di luar kegiatan sebagai guru) sebagai obyek penelitian dengan jumlah posisi jabatan sebanyak 9 orang yang terdiri atas:

a. 1 orang Kepala Sekolah

b. 1 Wakabid. Kurikulum

c. 1 Wakabid. Kesiswaan

d. 1 Wakabid. Sarana Prasarana

e. 1 Wakabid. Humas

f. 1 orang Wali kelas

g. 1 orang Guru

h. 1 orang $\mathrm{BP} / \mathrm{BK}$

i. 1 orang Tata Usaha

\section{Indentifikasi Data Pekerjaan Saat Ini}

Identifikasi dilakukan pada setiap posisi jabatan pada area yang ditentukan serta membutuhkan data pekerjaan saat ini dari masing-masing pemegang posisi tersebut, untuk mendapatkan data identitas jabatan serta tugas-tugas yang ada. Disamping itu data kualifikasi juga dibutuhkan untuk melihat kompetensi posisi jabatan terhadap tugas yang ada.

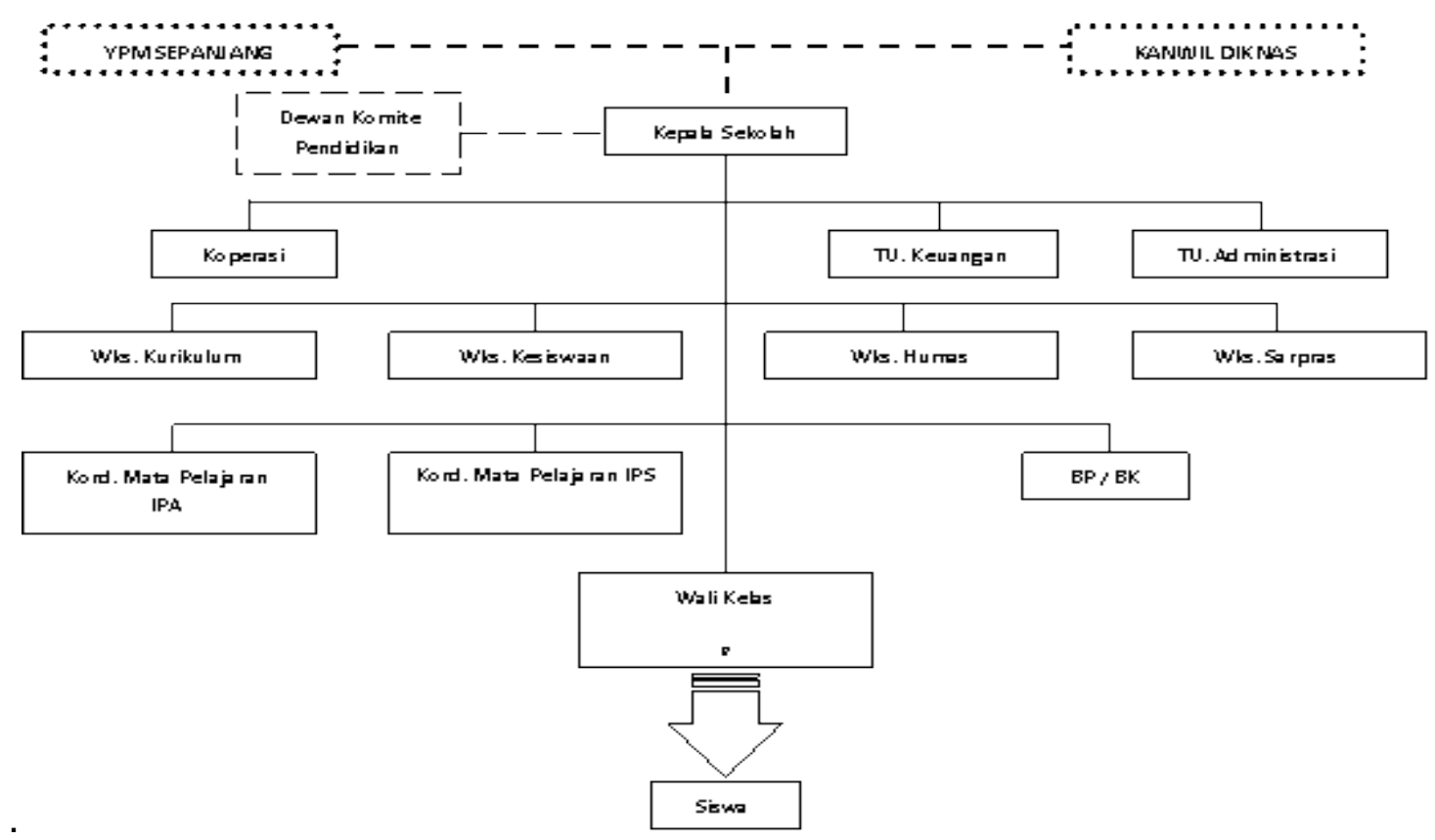

Gambar 1. Struktur Organisasi SMA XYZ Sukodono 
Tabel 1. Rekapitulasi Hasil Kuisioner

\begin{tabular}{|l|l|c|c|c|}
\hline NO & \multicolumn{1}{|c|}{ JABATAN } & WAKTU TOTAL TUGAS & VALIDASI & KETERANGAN \\
\hline \hline 1. & Kepala Sekolah & 25,92 & $100 \%$ & - \\
\hline 2. & Wakabid. Kurikulum & 24,44 & $100 \%$ & - \\
\hline 3. & Wakabid. Kesiswaan & 98,75 & $92 \%$ & Overload \\
\hline 4. & Wakabid. Humas & 1,23 & $70 \%$ & - \\
\hline 5. & Wakabid. Sarpras & 7,81 & $80 \%$ & - \\
\hline 6. & Wali Kelas & 8,40 & $100 \%$ & - \\
\hline 7. & Guru & 66,30 & $100 \%$ & Overload \\
\hline 8. & BP/BK & 54,33 & $100 \%$ & Overload \\
\hline 9. & Tata Usaha & 109,33 & $100 \%$ & Overload \\
\hline
\end{tabular}

\section{Pengumpulan Data}

Proses pengumpulan data dilakukan dengan metode kuisioner. Kuisioner ini dibuat untuk mendapatkan waktu kerja pada setiap tugas dari masing-masing pemegang posisi. Proses validasi pekerjaan dilakukan juga melalui pengisian kuesioner bagi masing-masing pemegang posisi jabatan. Telah disepakati dengan pihak manajemen sekolah bahwa proses penentuan waktu kerja dalam satuan jam atau satuan waktu lainnya ditentukan langsung oleh posisi jabatan pada kuisioner yang ada dan dibantu dengan pengarahan dari pihak sekolah.

Proses perhitungan waktu kerja dilakukan dengan tahapan sebagai berikut:

1. Kuisioner dibuat dari hasil identifikasi pekerjaan saat ini yang dilakukan pada setiap posisi jabatan. Seluruh tugas yang dibebankan pada posisi jabatan terkait ditentukan waktu pengerjaannya oleh masing-masing responden. Dari data pekerjaan saat ini, yang termasuk dalam kategori tugas posisi adalah tugas rutin.

2. Kuisioner mengidentifikasi apakah tugas tersebut benar dilakukan sesuai kondisi yang ada atau tidak dilakukan.

3. Kuisioner juga mengidentifikasi bagaimana tugas-tugas tersebut mengalami perulangan (frekuensi tugas) yang dapat dikelompokkan menjadi 5 kategori, yaitu:

a. Jika harus mengulang tugas tersebut setiap hari.

b. Jika harus mengulang tugas tersebut setiap minggu.

c. Jika harus mengulang tugas tersebut setiap bulan.

d. Jika harus mengulang tugas tersebut setiap semester atau tiap 6 bulan.

e. Jika harus melakukan tugas tersebut sekali dalam setahun.

Kuisioner diberikan kepada setiap posisi jabatan pekerjaan. Seluruh tugas yang dibebankan pada posisi jabatan terkait harus ditentukan apakah dikerjakan sesuai kenyataan yang ada, berapa waktu pengerjaannya, serta bagaimana frekuensi pengerjaannya. Sebagaimana telah ditentukan sebelumnya, penentuan waktu kerja ini merupakan pendapat atau penilaian langsung dari posisi jabatan tanpa dilakukan pengukuran ulang waktu kerja.

\section{Pemetaan Pekerjaan}

Proses pemetaan pekerjaan dilaksanakan dengan cara melakukan pemetaan terhadap pekerjaan saat ini dari setiap posisi jabatan yang ada dengan matriks Job Mapping serta memasukkan hasil perhitungan waktu kerja pada setiap pekerjaan.

Data dari hasil kuisioner yang telah diserahkan kembali, selanjutnya diolah dengan bantuan program Excel dibuat dalam bentuk tabel, serta dilakukan normalisasi terhadap data waktu kerja yang ada dalam satuan waktu jam/minggu. Hal ini dilakukan untuk mempermudah memahami waktu kerja yang dibutuhkan dalam menyelesaikan tugas tersebut dalam waktu satu minggu.

Kolom validasi dipergunakan untuk mengetahui tentang tugas tersebut benar dilakukan atau justru tidak dilakukan, dimana nilai validasi dapat dihitung dengan membagi jumlah tugas-tugas yang memang dilakukan dengan jumlah seluruh tugas yang ada. Jika seluruh tugas yang ada dikerjakan, maka nilai dari validasinya adalah $100 \%$. Tetapi bila semakin banyak tugas yang ada bukan merupakan tugas yang dikerjakan oleh mereka, nilai validasi akan semakin kecil, yang berarti data jobdesc (pekerjaan saat ini) semakin tidak valid. Sebaliknya jika nilai validasi semakin membesar, yang berarti data jobdesc akan semakin valid.

Rekapitulasi hasil pengolahan seluruh kuisioner tersebut dapat ditampilkan pada Tabel 1. Dari tabel tersebut tampak bahwa terdapat 4 jabatan yang mempunyai waktu kerja overload, yaitu yang melebihi waktu kerja normal sebesar $6 \times 6=36$ jam perminggu. Sedangkan untuk nilai validasi tugas sebagian besar diatas $70 \%$ atau cukup valid.

\section{Pembuatan matriks Job Mapping}

Pembuatan matriks Job Mapping dimulai dengan mendefinisikan isi atau keterangan pada 
Tabel 2. Pemetaan Fungsi Strategis

\begin{tabular}{|c|c|c|c|c|c|c|}
\hline SMA YPM 2 & & & FUNGSI STRATEGIS I & ISTINC & & \\
\hline JABATAN & RJPS & wkt & Kebijakan & wkt & RKAS & wkt \\
\hline epala Sekolah & Merumuskan & 0,50 & Menetapkan & 0,50 & Menyusun & 0,50 \\
\hline & Mengatur & 0,10 & Memimpin Rapat & 0,75 & & \\
\hline & & 0,60 & & 1,25 & & 0,50 \\
\hline Vakil Kepala Sekolah & & & & & & \\
\hline Wakabid. Kurikulum & & & Penetapan kebijakan mutu & 12,00 & & \\
\hline & & & & 12,00 & & \\
\hline Wakabid. Kesiswaan & Bekerjasama dg Humas & 0,00 & $\begin{array}{l}\text { Menyampaikan TATIB } \\
\text { sekolah }\end{array}$ & 48,00 & & \\
\hline & & & $\begin{array}{l}\text { Membina \& melaksanakan } \\
6 \mathrm{~K}\end{array}$ & 48,00 & & \\
\hline & & 0,00 & & 96,00 & & \\
\hline Wakabid. Humas & & & Publikasi informasi sekolah & 001 & & \\
\hline & & & & 0,01 & & \\
\hline Wakabid Sarnas & & & & & Menvusun RKS Sarners & 050 \\
\hline & & & & & Menyusun Program inventaris & 0,06 \\
\hline & & & & & & 0,56 \\
\hline Vali Kelas & Berkoordinasido Wakabid & 0.25 & & & & \\
\hline & & 0,25 & & & & \\
\hline suru & Berkoordinasido Wakabid & 025 & & & & \\
\hline & & 0,25 & & & & \\
\hline & & & & & & \\
\hline $3 \mathbf{P} / \mathbf{B K}$ & & & & & Menyusun program BK & 8,00 \\
\hline & & & & & Program tindak lanjut & 6,00 \\
\hline & & & & & & 14,00 \\
\hline ata Usaha & & & Mo t lis & sop & Yr & 0.67 \\
\hline ata usanta & & & & 30,00 & Mengusur r Togram to & 0,067 \\
\hline COTAL WAKTU & 2,20 & & 278,52 & & 31,46 & \\
\hline
\end{tabular}

masing-masing posisi jabatan, yaitu fungsi pengelolaan pekerjaan bagian kolom, dan nama/struktur jabatan pada bagian baris. Fungsi pengelolaan pekerjaan yang ada sangat tergantung pada saat pemetaan dilakukan, termasuk beberapa jumlah fungsi pengelolaan yang ada akan menentukan berapa panjang kolom matriks tersebut. Untuk sisi baris, telah kita ketahui terdapat 9 posisi jabatan yang dapat dianalisis. posisi jabatan ini dapat diurutkan dari yang tertinggi hingga yang terendah sesuai area pekerjaan masing-masing hingga jumlah baris menjadi 9 buah.

\section{Melakukan Pemetaan Jobdesc}

Langkah selanjutnya adalah melakukan pemetaan terhadap pekerjaan saat ini dari setiap posisi jabatan yang ada yang merupakan bagian tersulit dari proses menormalisasikan beban kerja. Dari data pekerjaan saat ini di SMA XYZ Sukodono, diidentifikasi data-data dari tugas rutin dari para posisi jabatan.

Proses pemetaan dilakukan dengan cara:

a. Menentukan posisi atau nama jabatan tersebut, tugas-tugas yang harus dilakukan, serta pada fungsi pengelolaan apa tugas tersebut terkait.

b. Nama jabatan kita letakkan pada bagian baris, tugas-tugas yang ada kita letakkan pada isi matriks pada baris yang sama, sedangkan fungsi tugas tersebut kita letakkan pada bagian kolom yang menjadi fungsi pengelolaan.

Proses pemetaan ini dilakukan untuk para pemegang posisi jabatan sehingga akan kita dapatkan sebuah matriks yang menggambarkan distribusi seluruh tugas yang ada pada masingmasing fungsi pengelolaannya.

Data waktu kerja dari hasil kuisioner yang telah diolah selanjutnya diinputkan pada peta Job Maping. Hal ini dilakukan untuk mengetahui berapa lama seluruh tugas dapat dikerjakan oleh setiap posisi jabatan, serta untuk mengetahui seberapa lama suatu fungsi pengelolaan atau topik pekerjaan dapat dikerjakan oleh seluruh posisi jabatan yang terkait. Untuk sebagian hasil dari pemetaan yang dilakukan pada data tugas rutin dari seluruh posisi jabatan pada lingkup strategis, yang mana seluruh hasil pemetaan kondisi existing ini dapat dilihat pada Tabel 2.

\section{Melakukan Perbaikan Beban Kerja}

Proses utama dari perbaikan beban kerja adalah melakukan improvement hasil pemetaan jobdesc pada kondisi awal untuk mendapatkan deskripsi pekerjaan yang lebih baik bagi setiap posisi jabatan. Menurut Adriansyah (Adriansyah, 2009), proses perbaikan beban kerja ini dapat dilakukan dengan cara:

a. Jika tugas pada masing-masing posisi jabatan terlalu banyak (overload), maka dilakukan pendelegasian tugas.

b. Jika tugas pada masing-masing posisi jabatan terlalu sedikit (underload), maka dilakukan penambahan tugas.

c. Jika tugas pada masing-masing jabatan belum tepat kepentingannya, maka dilakukan perbaikan (perubahan prioritas). 
Tabel 3. Perbaikan waktu kerja untuk Wakabid. Kesiswaan

\begin{tabular}{|c|c|c|c|c|c|c|c|c|c|c|}
\hline \multirow{2}{*}{ TUGAS } & \multirow{2}{*}{ WAKABID KESISWAAN } & \multicolumn{5}{|c|}{ FREKUENSI TUGAS } & \multirow{2}{*}{$\begin{array}{l}\text { LAMA (JAM) } \\
\text { PENGERJAAN }\end{array}$} & \multirow{2}{*}{$\begin{array}{l}\text { NORMALISASI } \\
\text { MINGGUAN }\end{array}$} & \multirow{2}{*}{ VALIDASI } & \multirow{2}{*}{ KETERANGAN } \\
\hline & & $\mathbf{H}$ & $\mathbf{M}$ & B & $\mathrm{s}$ & $\mathbf{T}$ & & & & \\
\hline 1 & $\begin{array}{l}\text { Melaksanakan bimbingan, pengarahan dan } \\
\text { pengendalian kegiatan siswa dalam rangka } \\
\text { menegakan disiplin dan tata tertib sekolah }\end{array}$ & $\mathrm{v}$ & & & & & 8 & 48,00 & Ya & 6 - penyederhanaan \\
\hline 2 & $\begin{array}{l}\text { Merencanakan, melaksanakan dan mengevaluasi } \\
\text { program pembinaan kesiswaan/OSIS }\end{array}$ & & & $v$ & & & 1 & 0,25 & Ya & \\
\hline 3 & Membina pengurus OSIS dalam berorganisasi & & & $\mathrm{v}$ & & & 1 & 0,25 & Ya & \\
\hline 4 & $\begin{array}{l}\text { Menyusun program dan jadwal pembinaan siswa } \\
\text { secara berkala dan insidental }\end{array}$ & & & & $v$ & & 3 & 0,13 & $\mathrm{Ya}$ & \\
\hline 5 & $\begin{array}{l}\text { Membina dan melaksanakan koordinasi } \\
\text { keamanan, kebersihan, ketertibana, kerindangan } \\
\text { keindahan dan kekeluargaan }(6 \mathrm{~K})\end{array}$ & $v$ & & & & & 8 & 48,00 & Ya & 6 - penyederhanaan \\
\hline 6 & $\begin{array}{l}\text { Melaksanakan pemilihan calon siswa teladan dan } \\
\text { calon siswa penerima bea siswa }\end{array}$ & & & & $\mathrm{v}$ & & 0,5 & 0,02 & Ya & \\
\hline 7 & $\begin{array}{l}\text { Mengadakan pemilihan siswa untuk mewakili } \\
\text { sekolah dalam kegiatan di luar sekolah }\end{array}$ & & & $\mathrm{v}$ & & & 0,5 & 0,13 & Ya & \\
\hline 8 & Menyusun program kegiatan ekstrakulikuler & & & & & $\mathrm{v}$ & 3 & 0,06 & $\mathrm{Ya}$ & \\
\hline 9 & $\begin{array}{l}\text { Menyusun laporan pelaksanaan kegiatan } \\
\text { kesiswaan secara berkala }\end{array}$ & & & & $v$ & & 16 & 0,67 & Ya & \\
\hline 10 & $\begin{array}{l}\text { Bekerjasama dengan humas untuk pelaksanaan } \\
\text { kegiatan hari-hari besar dan hari-hari keagamaan }\end{array}$ & & & & & & & 0,00 & Tidak & \\
\hline 11 & $\begin{array}{l}\text { Melaksanakan kegiatan MOS dan perpisahan } \\
\text { siswa }\end{array}$ & & & & & $\mathrm{v}$ & 24 & 0,50 & $\mathrm{Ya}$ & \\
\hline 12 & $\begin{array}{l}\text { Melaksanakan evaluasi dan melaporkan kegiatan } \\
\text { kepada kepala sekolah }\end{array}$ & & & v & & & 3 & 0,75 & Ya & \\
\hline & & & & & & & Total Waktu & 98,75 & $92 \%$ & \\
\hline
\end{tabular}

d. Jika tugas pada masing-masing jabatan tumpang tindih, maka dilakukan cara pemilihan tugas yang tepat (menghilangkan yang tidak diperlukan).

e. Jika tugas pada masing-masing jabatan terlalu kompleks, maka dilakukan cara penyederhanaan (lebih mudah dan lebih cepat).

Pada penelitian ini, dilakukan proses dengan cara melihat tugas-tugas mana saja dari setiap posisi jabatan yang overload dan mempunyai waktu pengerjaan yang cukup banyak, selanjutnya dilakukan perbaikan dengan cara mendelegasikan tugas-tugas tersebut kepada posisi jabatan lainnya yang masih mempunyai waktu kerja yang cukup sedikit serta mempunyai kompetensi untuk menerima pengalihan tugas tersebut. Namun, bila tugas tersebut tidak bisa didelegasikan kepada staf lainnya, maka proses improvement dilanjutkan pada tugas lainnya yang dapat didelegasikan. Proses perbaikan lain yang dapat dilakukan adalah jika tugas tersebut terlalu tinggi waktu dengan kompleksitasnya, maka dilakukan penyederhanaan tugas yang dapat membantu mengurangi waktu pengerjaan tugas. Proses penyederhanaan pekerjaan ini dilakukan dengan cara menata ulang cara penyelesaian pekerjaan yang ada dan telah didsikusikan dengan pemegang jabatan dan pimpinannya. Demikian seterusnya perbaikan waktu kerja dilakukan untuk mengurangi waktu pengerjaan hingga tercapai total waktu kerja yang diharapkan, yaitu kurang dari 36 jam per-minggu.

Proses improvement atau usulan perbaikan utamanya dilakukan pada tugas-tugas pendukung atau operasional yang masih dapat didelegasikan, sedang pada tugas-tugas strategis atau tugas-tugas yang membutuhkan keahlian atau kompetensi khusus sebaiknya tidak didelegasikan untuk menghindari kesalahan dalam penyelesaian pekerjaan tersebut. Proses perbaikan yang dapat dilakukan pada jabatan-jabatan yang mempunyai kondisi overload tersebut adalah sebagai berikut:

\section{Wakabid. Kesiswaan}

Dari hasil pemetaan didapatkan beberapa tugas mempunyai waktu yang besar. Namun ada beberapa tugas yang mampu disederhanakan durasi waktu pengerjaannya, sehingga didapat waktu pengerjaan tugas yang lebih kecil. Diantaranya tugas-tugas tersebut adalah:

a. Melaksanakan bimbingan, pengarahan dan pengendalian kegiatan siswa dalam rangka menegakkan disiplin dan tata tertib sekolah. Dengan lama waktu pengerjaan dari 8 menjadi 6 jam/minggu.

b. Membina dan melaksanakan koordinasi keamanan, kebersihan, ketertiban, kerindangan, keindahan dan kekeluargaan (6K). Dengan lama waktu pengerjaan dari 8 menjadi 6 jam/minggu.

Perbaikan pada jabatan Wakabid. Kesiswaan ini dapat dilihat pada Tabel 3.

\section{BP/BK}

Demikian juga dari hasil pemetaan untuk jabatan BP/BK didapati kondisi beberapa tugas mempunyai waktu yang besar tetapi dalam pengerjaannya diperlukan keahlian dan kompetensi khusus yang berarti tidak bisa didelegasikan kepada staf lainnya. Sehingga hanya ada beberapa tugas yang mampu disederhanakan durasi waktu pengerjaannya, maka di dapat waktu pengerjaan tugas yang lebih kecil. Diantaranya tugas-tugas tersebut adalah: 
Tabel 4. Perbaikan Waktu Kerja Untuk BP/BK

\begin{tabular}{|c|c|c|c|c|c|c|c|c|c|c|}
\hline \multirow{2}{*}{ TUGAS } & \multirow{2}{*}{ BP/BK } & \multicolumn{5}{|c|}{ FREKUENSI TUGAS } & \multirow{2}{*}{$\begin{array}{l}\text { LAMA (JAM) } \\
\text { PENGERJAAN }\end{array}$} & \multirow{2}{*}{$\begin{array}{l}\text { NORMALISASI } \\
\text { MINGGUAN }\end{array}$} & \multirow{2}{*}{ VALIDASI } & \multirow{2}{*}{ KETERANGAN } \\
\hline & & $\mathbf{H}$ & M & B & $\mathbf{S}$ & $\mathbf{T}$ & & & & \\
\hline 1 & $\begin{array}{l}\text { Menyusunan dan melaksanakan } \\
\text { program bimbingan dan konseling }\end{array}$ & & $v$ & & & & 8 & 8,00 & Ya & $\begin{array}{c}6- \\
\text { penyederhanaan }\end{array}$ \\
\hline 2 & $\begin{array}{l}\text { Koordinasi dengan wali kelas } \\
\text { dalam rangka mengatasi masalah- } \\
\text { masalah yang dihadapi anak didik } \\
\text { tentang kesulitan belajar }\end{array}$ & $v$ & & & & & 0,5 & 3,00 & Ya & \\
\hline 3 & $\begin{array}{l}\text { Memberikan layanan dan } \\
\text { bimbingan kepada anak didik agar } \\
\text { lebih berprestasi dalam kegiatan } \\
\text { belajar }\end{array}$ & $v$ & & & & & 1 & 6,00 & Ya & \\
\hline 4 & $\begin{array}{l}\text { Memberikan saran dan } \\
\text { pertimbangan kepada anak didik } \\
\text { dalam memperoleh gambaran } \\
\text { tentang lanjutan pendidikan dan } \\
\text { lapangan pekerjaan yang sesuai }\end{array}$ & $\mathrm{v}$ & & & & & 3 & 18,00 & Ya & \\
\hline 5 & $\begin{array}{l}\text { Mengadakan penilaian pelaksanaan } \\
\text { bimbingan dan konseling }\end{array}$ & & $v$ & & & & 8 & 8,00 & Ya & $\begin{array}{c}6- \\
\text { penyederhanaan }\end{array}$ \\
\hline 6 & $\begin{array}{l}\text { Menyusun statistic hasil penilaian } \\
\text { bimbingan dan konseling }\end{array}$ & & & & $v$ & & 16 & 0,67 & Ya & $\begin{array}{c}12- \\
\text { penyederhanaan }\end{array}$ \\
\hline 7 & $\begin{array}{l}\text { Melaksanakan kegiatan analisis } \\
\text { hasil evaluasi belajar }\end{array}$ & & & $v$ & & & 16 & 4,00 & Ya & \\
\hline 8 & $\begin{array}{l}\text { Menyusun dan melaksanakan } \\
\text { program tindak lanjut bimbingan } \\
\text { dan konseling }\end{array}$ & & & $v$ & & & 24 & 6,00 & Ya & \\
\hline 9 & $\begin{array}{l}\text { Menyusun laporan pelaksanaan } \\
\text { kegiatan bimbingan dan konseling }\end{array}$ & & & & v & & 16 & 0,67 & Ya & \\
\hline & & & & & & & Total Waktu & 54,33 & $100 \%$ & \\
\hline
\end{tabular}

Tabel 5. Rekapitulasi Perbaikan Kerja

\begin{tabular}{|c|l|c|c|c|}
\hline NO & \multicolumn{1}{|c|}{ JABATAN } & $\begin{array}{c}\text { WAKTU TOTAL } \\
\text { SEBELUM }\end{array}$ & $\begin{array}{c}\text { WAKTU TOTAL } \\
\text { SESUDAH }\end{array}$ & KETERANGAN \\
\hline \hline 1. & Kepala Sekolah & 25,92 & 25,92 & - \\
\hline 2. & Wakabid. Kurikulum & 24,44 & 24,44 & - \\
\hline 3. & Wakabid. Kesiswaan & 98,75 & 74,75 & overload \\
\hline 4. & Wakabid. Humas & 1,23 & 1,23 & - \\
\hline 5. & Wakabid. Sarpras & 7,81 & 7,81 & - \\
\hline 6. & Wali Kelas & 8,40 & 8,40 & Overload \\
\hline 7. & Guru & 66,30 & 66,30 & Overload \\
\hline 8. & BP/BK & 54,33 & 50,17 & Overload \\
\hline 9. & Tata Usaha & 109,33 & 109,33 & $\mathbf{3 6 8 , 3 5}$ \\
\hline \multicolumn{2}{r|}{ TOTAL WAKTU } & $\mathbf{3 9 6 , 5 1}$ & & \\
\hline
\end{tabular}

a. Menyusun dan melaksanakan program bimbingan konseling. Dengan lama waktu pengerjaan dari 8 menjadi 6 jam/minggu.

b. Mengadakan penilaian pelaksanaan bimbingan dan konseling. Dengan lama waktu pengerjaan dari 8 menjadi 6 jam/minggu.

c. Menyusun statistik hasil penilaian bimbingan dan konseling. Dengan lama waktu pengerjaan dari 16 menjadi $12 \mathrm{jam} / \mathrm{minggu}$.

Perbaikan pada posisi jabatan BP/BK ini dapat dilihat pada Tabel 4.

\section{Guru}

Hasil pemetaan untuk posisi jabatan guru didapati kondisi tugas yang mempunyai waktu besar, namun beban kerja tidak boleh dialihkan ke posisi jabatan lain dikarenakan tugas tersebut memang menjadi tugas inti dari seorang guru. Solusinya adalah tugas-tugas tersebut yang sekiranya dapat dikerjakan dirumah ataupun dilakukan pada saat tidak ada jam mengajar.

\section{Tata Usaha}

Namun hasil pemetaan untuk jabatan Tata Usaha didapati kondisi tugas yang mempunyai waktu besar dan dalam pengerjaannya diperlukan keahlian dan kompetensi khusus yang berarti tidak bisa didelegasikan kepada staf lainnya. Solusinya adalah dengan penambahan staf pendukung untuk mengurangi beban kerja yang overload pada posisi jabatan Tata Usaha.

Rekapitulasi dari proses perbaikan yang dilakukan pada setiap posisi jabatan ini dapat dilihat pada Tabel 5. Pada tabel tersebut, masih terdapat kondisi overload pada 4 posisi jabatan meskipun telah dilakukan perbaikan beban kerja, tapi ada 2 posisi jabatan yang mampu dikurangi beban kerjanya meskipun masih belum mampu mengurangi beban kerja yang diharapkan sesuai 36 jam per-minggu yaitu posisi Wakabid. Kesiswaan dan BP/BK. Untuk Wakabid. Kesiswaan yang awalnya total waktu kerja 98,75 jam/minggu, kini menjadi 74,75 jam/minggu. Sedangkan untuk 
posisi jabatan BP/BK yang awalnya total waktu kerja 54,33 jam/minggu, hanya mampu diturunkan menjadi 50,17 jam/minggu. Secara keseluruhan total waktu kerja untuk seluruh pekerjaan adalah sebesar 396,51 jam/minggu dan setelah diadakan proses perbaikan menjadi 368,35 jam/minggu.

\section{PENUTUP}

Dari hasil penelitian dan pengolahan data yang dilakukan di SMA XYZ Sukodono, didapatkan kesimpulan, telah dilakukan pemetaan terhadap 92 tugas (pekerjaan) dalam matriks JM berukuran $9 \mathrm{x}$ 17 dengan hasil 4 jabatan dalam kondisi overload dengan total waktu kerja untuk semua adalah 396,51 jam per-minggu. Dan posisi jabatan Tata Usaha yang mempunyai beban kerja tertinggi sebesar 109,33 jam per-minggu.

Perbaikan beban kerja dilakukan untuk kondisi overload 4 jabatan yaitu Wakabid. Kesiswaan, Guru, BP/BK, dan Tata Usaha. Namun, proses ini hanya mampu mengurangi total waktu kerja untuk semua fungsi pengelolaan yang awalnya 396,51 jam per-minggu menjadi 368,35 jam per-minggu.

Secara umum proses penurunan beban kerja yang overload sulit dilakukan karena dibutuhkan keahlian dan kompetensi khusus yang berarti tidak bisa didelegasikan kepada staf lainnya. Disarankan untuk menambah jumlah tenaga kerja pada posisiposisi tersebut untuk membagi beban kerja yang ada, tentunya dengan keahlian dan kompetensi yang dibutuhkan serta kemampuan institusi dalam merekrut tenaga kerja tambahan.

\section{DAFTAR PUSTAKA}

Adriansyah, G. (2009). Pendekatan job mapping sebagai alat bantu dalam desain ulang pekerjaan. Universitas Indonesia. Fakultas Teknik.

Anshori, M., Fudhla, A. F., \& Hidayat, A. (2017). Penentuan Lokasi Fasilitas Crossdock pada Kota Metropolis dengan Pendekatan Center Of Gravity. Teknika: Engineering and Sains Journal, 1(2), 83-88.
Ardhyani, I. W. (2017). Mengoptimalkan Biaya Distribusi Pakan Ternak dengan Menggunakan Metode Transportasi (Studi Kasus di PT. X Krian). Teknika: Engineering and Sains Journal, 1(2), 95-100.

Ardhyani, I. W., \& Singgih, M. L. (2017). Pengukuran Kualitas Layanan dengan Higher Education Performance (HEdPERF) dan Higher Education Service Quality (HiEdQUAL). Teknika: Engineering and Sains Journal, 1(1), 25-32.

Aziza, N., \& Nurcahyo, Y. E. (2017). Model Rancangan Pengukuran Kinerja dengan Pendekatan Metode Integrated Performance Measurement System. Teknika: Engineering and Sains Journal, 1(1), 33-40.

Denton, D. K. (1992). Redesigning a job by simplifying every task and responsibility. Industrial Engineering, 24(8), 46-48.

Gryna, F. M. (2004). Work overload!: Redesigning jobs to minimize stress and burnout. ASQ Quality Press.

Hackman, J. R., \& Oldham, G. R. (1975). Development of the job diagnostic survey. Journal of Applied Psychology, 60(2), 159.

Mulyono, M. A. (2008). Manajemen Administrasi dan Organisasi Pendidikan. Ar-Ruzz Media, Yogyakarta.

Nur, A. (2012). Dasar-dasar manajemen pendidikan. Bandung: CV Pustaka Cendekia Utama.

Rachmawati, I. K. (2008). Manajemen sumber daya manusia. Yogyakarta: Andi Offset.

Retnowati, D. (2017). Analisa Risiko K3 dengan Pendekatan Hazard and Operability Study (HAZOP). Teknika: Engineering and Sains Journal, 1(1), 41-46.

Wirjana, B. R. (2007). Mencapai Manajemen Berkualitas: organisasi, kinerja, program. Yogyakarta: Andi. 
G Adriansyah, dkk / Teknika : Engineering and Sains Journal, Vol. 2, No.1, Juni 2018, 59-66

Halaman ini sengaja dikosongkan 